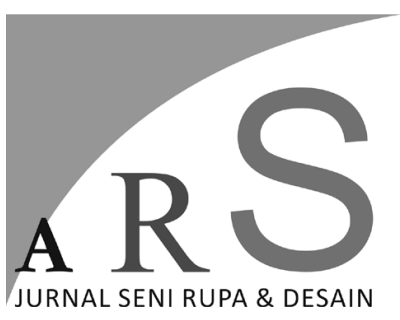

Volume 21 Nomor 2 - Agustus 2018

\section{ART AND CRAFT IN THE ERA OF CREATIVE INDUSTRY IN MALAYSIA}

\author{
Mumtaz Mokhtar \\ Faculty of Art \& Design, Universiti Teknologi \\ MARA, 40450 Shah Alam, Selangor. \\ E-mail :mumtazmikaeil@gmail.com
}

\begin{abstract}
ABSTRAK
Malaysia ditargetkan untuk menjadi sebuah negara maju pada tahun 2020. Makalah ini bertujuan untuk menanamkan sebuab ideologi bahwa kriya adalah sebuah penciptaan seni tinggi yang berkenaan dengan hasil yang bermakna, penuh kehati2an, dan kecerdasan. Untuk membangun sebuah kerangka seni dan kriya yang inklusif, paper ini meninjau perkembangan kriya dan seni di Malaysia. Diskusi epistimologis tentang definisi seni dan kriya sebagai elemen2 yang bisa memastikan keberhasilan industri kreatif. Kombinasi seni, kriya, dan estetika melayu menyediakan lebih banyak petunjuk tentang bagamana idustri kreatif seharusnya dibangun. Terlebih lagi, beberapa inisiatif dari Malaysia dipresentasikan untuk menggambarkan bagamana Malaysia mengelola negara menyonsong tahun 2050. Industri-industri kreatif di Malaysia memiliki potensi yang sangat tinggi untuk dikembangkan dan harus didukung oleh baik pemerintah maupun sektor swasta. Peneliti percaya bahwa kolaborasi aktif dan dinamis, eksplorasi media baru, kerjasama antar disiplin ilmu dan inovasi akan menjadi isu 2 penting untuk dipikirkan dalam pengembangan seni dan kriya dalam era industri kreatif.
\end{abstract}

Kata Kunci: seni, kerajinan, industri kreatif

\begin{abstract}
Malaysia is targeted to become a developed county in the year 2020. This paper aims to establish an ideology that craft is a high art creation that deals with intellectual, careful and meaningful output. In order to develop an inclusive framework about art and craft, this paper reviews the development of craft and art in Malaysia. The epistemological discussion on the definition of art and craft will offer a fresh spectacle on art and craft as elements that can ensure the success of the creative industry. The combination of art, craft and Malay aesthetics provides more clues on how the creative industry can go about. In addition, several initiatives from Malaysia are presented due to illustrate how Malaysia engineered the country towards 2050. Creative industries in Malaysia have a very high potential to be developed and should supported by the government as well as the private sector. This researcher believes that active and dynamic collaboration, new media exploration, cross discipline and innovation will be the crucial issues to be considered in the development of art and craft in the era of creative industry.
\end{abstract}

Keywords: art, craft, creative industry 


\section{Introduction}

As nations progress towards development, we often find traditional art and crafts being sidelined in favour of more modern products. Similarly, as Malaysia heads towards developed-nation status, many handicraft such as mat weaving and birdcage construction are effectively lost. This paper aims to establish an ideology that craft is a high art creation that deals with intellectual, careful and meaningful output. In order to develop an inclusive framework about art and craft, this paper reviews the development of craft and art in Malaysia. The epistemological discussion on the definition of art and craft will offer a fresh perspective on art and craft as elements that can ensure success to the creative industry.

Malaysia, situated in of Southeast Asia, is made up of the Semenanjung, and Sabah and Sarawak in the Borneo Island. The dominant population is Malays with Islam as it formal religion. Malaysia is designed to be a developed nation in 2020 based on the Vision 2020. Following that, the present and $6^{\text {th }}$ Prime Minister Dato' Sri Mohammad Najib Tun Abdul Razak, has made a restructuring of the country's development called National Transformation Program (TN50) for the year 2050.

\section{Malaysian Craft and Art Background}

Art and craft appeared since the earliest of time when human starts to think creatively to solve problems in everyday living. In early civilisations, technology was already created and absorbed when humans face new experiences from their environment. Also, the need to communicate and express their observation started to emerge. Hence, people start to create something that can be usable, deliver massage, sign, and so on until they create their own tradition. This process continues today as tradition become more advanced, demanding, and fascinating. However, all the form of creation depends or originates from their traditional and culture itself. The use of material always depend and appropriate to the natural environment, such as stone, wood, clay, trees and so on.

\section{Malaysian Crafts}

It is believed that the earliest artistic objects found in Malaysia were from the Mesolithic period (c.40 000-2500 BCE) (Jamal, 2007). Craft starts to cultivate during the Neolithic period with visual marks traced in megalith found in Pengkalan Kempas, Negeri Sembilan. The megaliths were called the Rudder, the Spoon and the Sword. One of it consists of high artistic carved relief with Kufic script. Tombstones with Islamic Motifs were also found dated in 1303 that shows Islam came to the country after Buddhism and Hinduism. Since 2000BC - 400CE, plaiting/weaving creations were done by women for their utilitarian and domestic needs. Beside pandanus mat, there were also rattan mats made by Sarawak indigenous natives such as the Kayan, Kenyah and Penan. They explore identical motif such as Star (Buah Bintang), trivet (Buah Tungku), leopard claws (buah kukut remaung) and fishing spear with bard (buah ruit).

Batik in Malaysia was started since the 1920s. It began with wooden batik blocks or batik cop without wax. The motif called pucuk rebung located in the kepala kain panel and flower bouquets were arranged in diagonal orientation as part of batik found in the 30s. Jamal (2007) mentioned that there was no batik production during 1940s due to the Japanese occupation. However, the batik industry was revived in the 50s. With the support of government agencies RIDA and MARA, batik productions flourish after that. Tjanting was introduced in the $60 \mathrm{~s}$ with several innovations in batik, including its types of cloth and its motif. Not only batik, songket too were also established in Malaysia. Songket weaving is dominantly explored in the east cost of Malaysia, especially in Kelantan and Terengganu. It used to be a family industry and having their own styles and motifs. Tekad, which is needle work in relief is also established among the Malays. It is a kind of embroidery using gold or silver thread on velvet. Since this craft uses gold material, which is considered expensive, in the olden days, this textile is worn only by royalty. Another textile art established in Malaysia is called kain telepuk or gilding. The Malays stamped gold leaf over woven cloth and produced several motifs that are similar to songket. Most of batik, songket and telepuk involve motifs based on flora, fauna, geometrics, the cosmos, and sometimes, food. 
Most motifs are presented in abstract form in accordance to Islamic Principles.

Metal workmanship consists of traditional weapons, silverware and jewelry. Traditional weapons such as the keris is considered "mystical" and is featured containing transcendental power. However, nowadays, they are just ceremonial symbols. Silverware such as silver coins (octagonal gold kupang), combs, belt, tobacco boxes and sireh set were commonly used by early Malay society. Jewelry was normally used by the royals since the Melaka Sultanate, but today Malaysians use jewelry extensively and in more modern styles.

\section{Malaysian Art}

Modern art was developed through the process of colonialism, migration and education in Malaysia, as mentioned by Muliyadi (2007). Western education especially, provides a turning point for Malaysian visual artists to develop and change techniques and media as well as their thinking. In the 1930s, modern art emerged in Malaysian when artists started to express their feelings. They used their observation of the environment as a reference to capture the visual image, visual experience and visual culture. These give a big impact to them, which they recorded using the soft material such as water color. Examples of these artists are Abdullah Ariff, Yong Mun Sen, O. Don Peris and other watercolorists in Penang. Furthermore, these pioneers started to introduce new approaches in local visual tradition by using western easel painting techniques to present their expression. Form started to change from the traditional ideology to western interpretation. However, the local experience still remains as their reference to create the visual idea.

Watercolor Painting focused on landscape that indirectly records the beauty of Malaysian environment. Contextually, the image frames the time and period of the artist reacting to their situation, culture, and environment. Besides landscapes, they also document figurative subjects with daily activities.

Artists move from watercolor to other mediums such oil paint, which they used with different subject matters and themes. Thus, in the $60 \mathrm{~s}$, artists turn to expressionism and abstract- expressionism styles. Nevertheless, their messages and subjects still embrace local experience. This is very apparently visualized in Syed Ahmad Jamal work's such "Tulisan". Artist Latiff Mohidin creates "Pago-pago" that turns regional images abstract. Sculptural artist Anthony Lau showed the form of abstraction in his work entitled 'Jungle'. New manifestos and ideology of visual art change when Syed Ahmad Jamal arouse Islamic manifestation in 1978 through his work "Gunung Ledang" using oil on canvas.

In 1980s, a new wave spreads to the Malaysian art platform when technology is incorporated into art. There are certain Eras when technology takes a part in Malaysia Art. These include the Programming Era, Paint Program Era and Multimedia Era (Mumtaz, 2012). In the early stages of technology wave, artists form the idea using the programs equipped in computers. Artists such Kamarudzaman starts using BASIC, Apple II,64RAM monochrome screen and mono sound to form his portrait painting. Then, in the Paint Program Era, developments in technology witness the exploration of LED wire in Alwi's work and digital collage in Ismail Zain's work.

In 1990s, Malaysian art became more complex when Hasnul Jamal Saidon created Computer animation installation and Liew Kung Yu used video with psychical sculpture. That era was labeled by Mumtaz (2012) as a Multimedia Era that showed the complexity of art in Malaysia. After the 1990s, new artists appeared with complicated ideas and elements in their creations. An example is the web-based artwork by Niranjan. Here, art elements are appearing inside a new world such as the virtual space. However, this is not beyond the usual understanding of art elements. Instead of manipulating common visual art language, the creation of digital art enhanced the visual understanding and interpretation. Whilst space in canvas painting is limited to the size of its picture plane, the space in computer on the other hand, is provided by memory space, digital space and internet delivery virtual space.

Other experimental works such as Sound art installation performance by Kamal Sabran and Digital photography installation by Liew Kung Yu extend the understanding of art. So do other artworks such as Hybrid art, present Digital 
Video Installation by Mohd Fuad Md Arif and Multimedia Performance Installation by Fairuz Sulaiman. Moreover, the creations by those artist since 90's appeared as double identities of form that need to be understood as an extension from "non- technology" to technology. Here, nontechnology is described as a common element of art and technology as new element of art that exist inside a computer technology.

After modern art, artists still apply the idea of local elements but the material, technique, skill, visual reference and style keep changing according to the time. Hence, the status of craft is not static but it is a development of art that experienced by the artist's soul and spirit. The influence of westernisation is only manifested in the physical of seeing, technique and style. Yet, spiritually, in the artist remains the structure of a local wisdom absorbed in early living.

\section{Definition of Art and Craft}

Art and craft are usually understood separately. Art is usually considered as high art that can be appreciated in the global context. Meanwhile, craft is pessimistically ranked as low art because it is only used and appreciated by some people. Even though there are differences between art and craft, the epistemological approach leads this paper to connect the similarities that established both as high art.

\section{Definition of Art}

Art is defined as the making of beautiful things (Cambridge International dictionary of English, 1995). Mainly, procedures of art are aimed to invoke certain impact such as good looking, enjoyable or affecting the human senses. Aristotle claimed that artists produced artworks as their quest for knowledge such as in imitation of nature. Later on, artists started to express various ideas, which Plato said that art was produced to indulge artist desires. Art is always connected to the word beauty. Tolstoy (1828-1910) described beauty as an activity which gives pleasure and excitement to the human nerves system. When people see landscape painting with deep space, audience will feel calmness and the bluish tinge of a river sometimes inject certain imagination of watery sound and cool senses.
Art is also something skillfully constructed by human artist (Goguen, 2000). Therefore, an artist is someone who is very good in what hel she does (Cambridge International Dictionary of English, 1995). The criteria of a person who created art and called an artist are important. Vasari (1511-1574) in his texts called 'The Lives of Artists' (1568) showed the importance of identifying the background of the artist such as his school of thought and his influence of styles. According to him, the quality of art and the perfection of styles are based on the artist's mind and skill. In fact, he stated that it is essential to understand art through an artist's eye. Beside artist and art works, the audience and its social context are other components that constitute the word art. Therefore, Hauser (1892-1978) believed that it is important to analyze the social context in order to understand art. This is because art is produced by many factors that influenced the artist's creation and audience's perception such as education level, class interest and political impacts in the society. Art as an aesthetic production will be delivered through it formalistic arrangement, the subject and its content. In order to depict meaning, formalistic arrangement need to be translated according to context.

In summary, art relates to both creation (verb) and production (noun) (Figure 1) The art making process is considered as aesthetic artistic process, which Clive Bell clarified as significant form. Whereby art as an output is called aesthetic production.

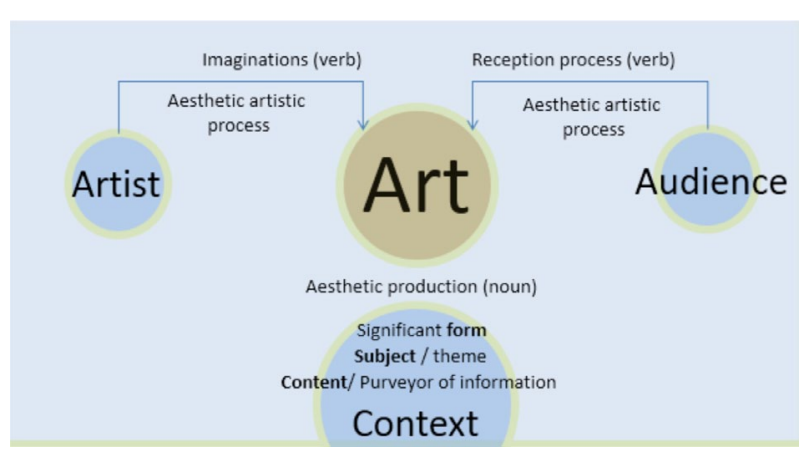

Figure 1: The components of art as production (noun) and art as the process (verb) 


\section{Definition of Craft}

The definition of crafts varies according to context. The New Oxford Dictionary (2009) and Merriam Webster Online Dictionary (2017) defined craft into two issues. Firstly, craft as a career and secondly, craft as a procedure of making art. Crafts as a career or job means a person who is involved in craft creations. It is considered as an occupation which require dexterity and also skill, which called them craftsman. Not everybody can be considered as craftsman because they have special criteria to establish them as craftsman. A good craftsman should have specific criteria including able to invent, formulating, or able to execute something. The craftsman established themselves as part of the society who carries their culture. Mohd Johari who cited Al-Ghazali mentioned that art become part of culture that is created by a group of people, ethnic, community or society in certain places. It is similar with Craig (2017) who said that craft was an important skill that was taught to the women of the tribes and villages. In addition, each group gives pleasure to their lives through art.

Secondly, craft in a context of planning and making deals with creative activity. It is about to put something in a proper way and with careful manner. The cautious intention is also accompanied by ingenuity. Beside hand skill, a state of mind is also a core elements in crafts creation because the craftsman is alert to the potential of media and reflects their surrounding effectively. Because of that, Ali (1989), elaborated that art is subjected to the inherited materials and nature as the main and the first experience in art creations.

While craft concern both the craftman and their skill, Kraftangan Malaysia defined crafts as;

"Keluaran Kraftangan" ertinya apa-apa
keluaran artistik yang mempunyai daya
tarikan kebudayaan atau tradisional
dan adalah hasil dari sesuatu proses yang
bergantung semata-mata atau sebahagiannya
kepada kemahiran tangan..."

(Act 222, Perbadanan Kemajuan Kraftangan Malaysia, 1979, Ammendment 2006)

Nevertheless, Harsman (2010) elaborated that all artworks are, actually a manifestation of one's knowledge which they presented in a very good skill craftsmanship. According to Ali (2012), craft product in Malay aesthetics considered six principles as below;

1. Prinsip Berhalus Fine Principles or finesse. Finesse refers to the appropriate choice of form and material (Idris, 2013). For example, that artists developed their idea based on stylization and denaturalization that was taken from the nature and choosing the appropriate medium to ensure the efficiency of artworks.

2. Prinsip Berguna Usefulness principle which served the intended function. It refers to the functions or usability of certain art objects (Idris, 2013). The usefulness are usually tangible or intangible. For example, a painting as part of interior decoration or expression of feelings and or Anyaman Tikar (mat weaving) that can be used for homeware and also aesthetic attraction.

3. Prinsip Bersatu Unity principle: It shows intricacy and delicacy of motifs and patterns in Malay traditional arts such as those found in Batik, wood carving and architecture. In visual arts, the unity principles of Malay aesthetic can be seen by the intricacy and delicacy of form and content in the works of art (Idris, 2013). For example, the wood carving in Malay where the composition of design is although rigid, but gives a beautiful meaning.

4. Prinsip Berlambang Symbolic principle, which is used to integrate and unify between form and contents. The principles of symbolism reveal the symbolic meaning of certain objects. For instance, Ali (1989) said that the Keris brings all the symbolic elements that are needed to strengthen Malay society.

5. Prinsip Berlawan Contrast Principle: The elements of contrast in Malay traditional arts refer to the various qualities which creates a sense of harmony (Idris, 2013). For example of wood carving that use natural and vegetal elements that have 
different entities which brings contrast and produce a flexibility towards harmony.

6. Prinsip Bermakna Meaningful Principle: All aesthetic creative comprise extrinsic and intrinsic meaning. In songket, identification of floral motifs or calligraphy motifs is easily discerned from its shapes and color arrangement. Meanwhile, its meaning is comprehended through its symbolism and translation of calligraphy words.

Briefly the understanding of craft in the context of Malay aesthetics is summarized in Figure 2. It also shows the importance of craftsmen and their intellectualism in creating products. Arba'iyah mentioned that;

"Songket Weaving will just be an object of utility that is put together neatly and beautifully if there is no aesthetics and philosophical values emerging from it" (Arbaiyah, 2016).

In Figure 3, lots of resemblance in components are shown between art and craft. An artist is considered as a craftsman who focuses on the psychomotor skill. On the other hand, the craftsman not only focuses on his hand works, he also works with his intellect. Art form involves several subcomponents that are reinforced with certain principles in order to see certain instincts and identities. Thus, six principles of Malay aesthetical approaches and the component of form, subject and content need to be addressed and blended together to produce meaningful and functional art.

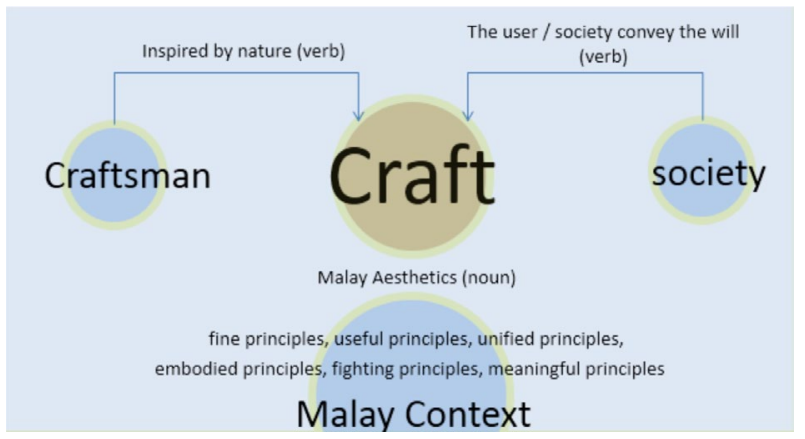

Figure 2: The components of craft as production (noun) and craft as the process (verb) in a context of Malay Aesthetics

\section{Art and Craft in Malaysia Creative Industry}

Malaysia starts to consider creative economy since the launching of Vision 2020 by the previous Prime Minister. Manufacturing and industrialization are examples of the progression along with several initiatives run by country such as smart school, manufacturing strategies and borderless marketing. Today, Malaysia is grappling with new constructive development through the National Transformation (TN50) by the current Prime Miniter Dato Sri Mohammad Najib bin Abdul Razak. Based on Dasar Industri Kreatif Negara (DIKN), creative industry is defined as;

“... industries that involve individual creativity, skills, and talents that have the potential to generate wealth as well creation of job opportunities through the promotion and exploitation of property intellectual" (DIKN, 2011).

Figure 4 illustrates how Malaysian art and craft could work in facing the creative industry challenges.

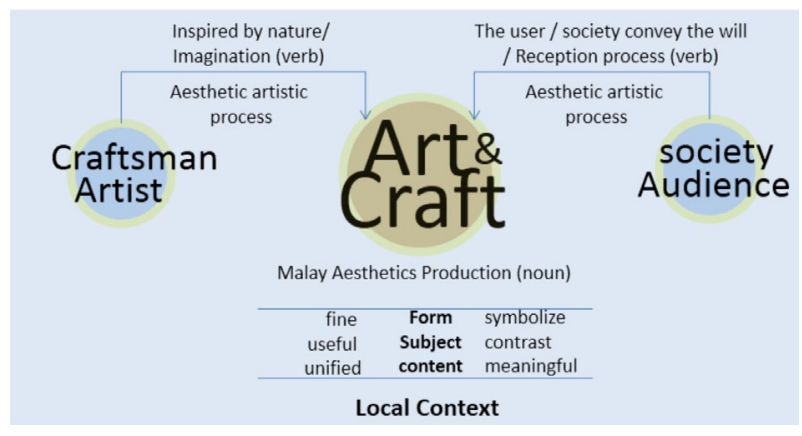

Figure 3: The alignment of art and crafts components as production (noun) and craft as the process (verb) in a context of Malay Aesthetics

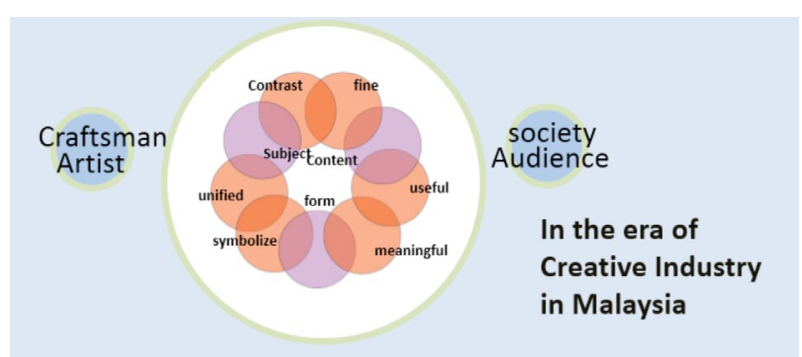

Figure 4: The convergence of art and crafts components In the Era of Creative Industry in Malaysia 
Visual art shows a positive development where modern art turns into contemporary art. Digital art in the contemporary period turns from multimedia era to paint program era and then, multimedia era. The multimedia era, especially during 1990s, shows good development towards new media and hybrid art. The complexity of form and its nature is transformed into data form, which is diverse and complex. In the early phase, visual artists like Syed Ahmad, Sulaiman Esa, Ponirin Amin and Ramlan Abdullah explored diversity of styles, methods, materials and technology such as fibre art, installation, metal and glass medium. This is continued with Hasnul Jamal Saidon,, Kamal Sabran, Fuad Arif and Fairus Sulaiman who explored new treatments including video, video installation, sound experimentation and site specific.

Painting is also included into craft and commercial products. Siti Zainon (abstract batik painter) has transformed her artwork into several commercial products such as gift box, case, wallet and tablet folder under the Siti Zainon brand. Dame Zandra Rhodes (established English fashion designer) presented the 2016 Autum / Winter collection based on Collaboration of Malaysian textile development program with Kraftangan Malaysia. Local entrepreneurs such as Fit Rebel implemented traditional batik art into new commercial legging products. Kraftangan Malaysia launched initiatives in promoting local craft items to commercial forms that is ongoing in Malaysia. Sayong Kuala Kangsar extend the vase production into table lamp and songket was used as exclusive gift packaging. There are many art business among local artists and craftsmen. Moreover, those who are in nonformal art background are also exploring the creative industry. Young talented film artiste, Emma Maembong who is also active in creating paintings, has developed her painting into a newly commercial form (scarf) called wearable art. Not even in the real business platform, art institution were also actively run research and development in cross art discipline through innovations. Fakhruradzi Yahaya successfully applied tenun Pahang motifs into jewelry design during his master program in Art \& Design in 2015. Hayree Anak Hashim with his Sapelele design won Modern Contemporary in the Craft Master Competition 2017. Transdisciplinary Art by Kamal Sabran (2013) showed the intersection of art, science and technology that displayed a new paradigm in art. The establishment of MYCREATIVEVENTURE Sdn Bhd. supported fashion and design establishment, traditional and cultural art and creative technology development such as dUCK, Zang Toi and Acurve Studio.

Based on the assertion of the above platforms, local art and craft showed periods of paradigm shift, which involve cross art discipline, established local identity, remained high in craftsmanship, production based on research, experimental and innovation mode, as well as business knowledge injection. Just to present several initiative to illustrate the track of success Malaysian creative industry, this paper list the initiatives according to government and public and private activities and research and development.

\section{Government Innitiatives}

1. KL International Craft Festival, Malaysia (23-26 November 2017)

2. National Innovation and Economy Expo NICE 2017: To Cultivate science technology and innovation (STI) among nation corresponding to $\mathrm{TN} 50$

3. CENDANA was launch (6 September 2017): To support performance art, craftworks, music, visual art, cultural art, marketing and arts. (9 Nov. 2017)

4. $16^{\text {th }}$ Convokcation for Institut Kraf Negara National Craft Institute

5. MY CREATIVE VENTURE SDN. BHD. (2012): Government investment to support Malaysia'sCreative industry.

6. Dasar Industri Kreatif Negara (DIKN) (2010): Play an important role in policy maker, fund and charity. Also concentrate on Multimedia Creative Industry, Creative Art Industry, and Cultural Heritage Industry.

7. Malaysian Digital Economy Corporation MDEC (1996): Agency in driving the digital economy in Malaysia.

8. Malaysian Design Council MRM (1993): to pave a future of innovation and design for Malaysia. 


\section{Public and Private Innitiatives}

1. Art \& Design Institution: Art \& Design UiTM, University of Malaya, LimKokWing University, Monash University etc.

2. Art Gallery \& Museum: National Visual Art Gallery, Islamic Art Museum,Segaris, GESTURZ etc

\section{Research}

1. Restructuring Tekat Motif as an Inspirationa Ceramic Divider, Faizun Abdullah, Norhidayah Md Zainuddin and Rusmadiah Anwar, ANDIC 2016

2. Copyright Laws and Digital Arts: Changes Ahead Under the trans-Pacific Patnership (TPP), Ellyana Tan, ANDIC 2016

3. Innovation in Heritage Products, Muhammad Abi Sofian Abdul Halim, Persidangan Seni Kebangsaan, 2009

4. Aspiration of Ethnic Crafts di Sarawak Rural Area, Nazlina Shaari, Noorhayati Suleiman, Persidangan Seni Kebangsaan, 2009

\section{Conclusion And Recommendations}

The mapping of art and craft components demonstrated craft as high art. The framework can also consider Islamic art perspective to widen global appreciation on art. Local artists and craftsmen have begun to explore art more widely starting with its creation until the production. Malay aesthetic principles show the identity of Malaysian art that comply to high intellectual properties. Malaysian creative industry is developing gradually and need more aggressive action to be taken by the government, public and private institutions. Research and innovation need to focus on the latest technologies and across the futuristic solution. Malaysians need to reflect to the national transformation, which is the central part of country's aim. It is not just beneficial to locals but also for international and global needs.

\section{References}

Ali, Abu, Isa, Siti Salwa., \& Suriawati, Siti. (2011). Development of Creative Industries in Malaysia as Experienced by Les' Copaque
Production. The Case Study. IEEE

Conference Publication.

Ali, Zakaria. (2012). Teori-Teori Seni: Bacaan Pilihan, Malaysia: Perpustakaan Negara Malaysia.

Aziz, Arba'iyah bt Ab. (2011). Mendekati Pemikiran dan Estetika dalam Kraftangan Melayu. Jurnal Perintis Pendidikan Seni Lukis \& Seni Reka. Jilid 19 dan 20, 2-10

Aziz, Arba'iyah bt Ab. (2016). Malay Songket: Its Philosophical Symbol and Meaning. Abstract book, Art and Design International Conference ANDIC2016, p.2

Aziz, Arba'iyah bt Ab. (2015). Songket: The Cultural, Heritage and Symbol of Malay Society. One Asia Foundation. Institut Teknologi Bandung Seminar 2015, International Course of Asian Community.

Hamid, Mohd Johari Ab. (2007). Falsafah dan Kritikan Seni. Malaysia: Universiti Pendidikan Sultan Idris.

Halim, Muhammad Abi Sofian Abdul. (2009). Inovasi di dalam Produk Warisan: Etika dan Estetika. Abstract book, Abstrak Persidangan Seni Kebangsaan, p.1.

Harsma, Kristin. (2010). Crossing the Devine Between Art \& Craft. Journal of Undergraduate Research, Vol.10, Article 4. Minnesota State University, Mankato

Idris, Nurkahzilah. (2013) Aspects of Malay Aesthetic in Syed Ahmad Jamal Artworks. in Proceeding, Seminar Penyelidikan Pemikiran \& Kepimpinan Melayu. Selangor: IMPAK, UiTM

Isa, Siti Suriawati. (2012). Development Issues for the Creative Economy in Malaysia (PhD's thesis). Queensland University of Technology.

Jamal, Syed Ahmad. (2007). Crafts and the Visual Arts. Singapore: Archipelago Press.

Mohamad, Mahathir. (1998). Excerpts from the Speeches of Mahathir Mohamad on the Multimedia Super Corridor. Malaysia: Pelanduk Publication (M) Sdn Bhd.MeriamWebster Online Dictionary (2017), Craft, Meriam Webster, Incorporated. Available: https://www.merriam-webster.com/dictionary/craft

Mahamood, Muliyadi. (2007). Malaysian Modern Art From the Pioneering Era to the 
Pluralist Era (1930s-1990s). Malaysia: Utusan Publication \& Distribution Sdn. Bhd.

Muray, C. (Ed.) (2003). Key Writers on Art: The Twentieth Century. London: Routledge

Mokhtar, Mumtaz. (2009). Digital Painting as New Media Art: A Conceptual and Technical Discussion. Abstrak Persidangan Seni Kebangsaan, p.44.

Musa, Helen, (2008). Malaysia Batik goes Global. Craft Arts International.

Laws of Malaysia. (Act 1979 Ammendment 2006 ). ACT 222: handicraft product. Malaysia
Procter, Paul (Ed.). (1995) Cambridge International Dictionary of English. Cambridge University Press.

Sheppard, M. (2011). Malay Art and Crafts. Malaysia: MBRAS.

Tan, Ellyana Meaning. (2016). Copyright Laws and the Digital Arts; Changes Ahead Under the Trans-Pacific Partnership (TPP). Abstract book from Art and Design International Conference ANDIC, p.17 